\title{
THE ECONOMY OF THE EXOTIC
}

\author{
THE RELATION OF SHELL ARCHITECTURE AND \\ INDUSTRIALIZATION IN HUNGARY BETWEEN 1949-1970
}

\author{
ORSOLYA GÁSPÁR* - ISTVÁN SAJTOS** \\ *architect, assistant lecturer. BME Department of Mechanics, Materials and Structures \\ 1111 Budapest, Müegyetem rkp. 3. Fax: (06 1) 463 1773. E-mail: gaspar@szt.bme.hu \\ **structural engineer, $\mathrm{PhD}$, associate professor, head of department. BME Department of Mechanics, \\ Materials and Structures \\ 1111 Budapest, Múegyetem rkp. 3. Fax: (06 1) 463 1773. E-mail: sajtos@szt.bme.hu
}

\begin{abstract}
The history of shell architecture is closely linked to the rapid industrialization of the first half of the 20th century. The large spans required for industrial buildings were most suitable for the developing structural systems based on reinforced concrete shells. Present paper studies the unique features of the development of shell architecture in Hungary, in comparison to other former socialist states and the West. The significance of individual engineering qualities as opposed to the international trends is studied via the evolution of the shell roofing designed for the KÖFÉM Factory. The different social-political context and the relative isolation of the Soviet Sphere of interest during the second half of the 20th century generated a mild western interest toward the 'exotic', the architectural developments of the eastern block. As the former socialist countries are recently coming to terms with their socialist architectural heritage, this interest is awakened. The short analysis of the western recognition of Hungarian industrial architecture in general and shell architecture in particular helps to understand its global and local relevance freed from the self-affirming interpretation of the contemporary socialist press.
\end{abstract}

Keywords: shell architecture, reinforced concrete, industrial architecture, structural analysis, socialist modernism

\section{INTRODUCTION}

“(...) The application of shells in Hungary is not characteristic. The large spans of the industrial buildings [a major field of application of shells in the region] are mainly solved with precast concrete frames and (Vierendeel) trusses. " (Rühle, 1957) ${ }^{1}$ Hermann Rühle, an acclaimed expert of shells from the GDR began his review about Hungarian shell architecture with these words in 1957, while taking part on the annual conference of concrete shell roof construction in Oslo. In the very same conference, Ove Arup, one of the most influential structural engineers of the $20^{\text {th }}$ century claimed the 'honeymoon' period of shells to be over, expecting shells to be used further on more consciously and, consequently, less frequently (Arup, 1957).

In 1957, shell architecture had already reached its peak in the Western World, yet, it barely started in Hungary. However controversial opening is the quote above from Rühle for this article, in its bare honesty together with the remark of Arup they sum-

${ }^{1}$ See 'Appendix' for the full citation in original. 


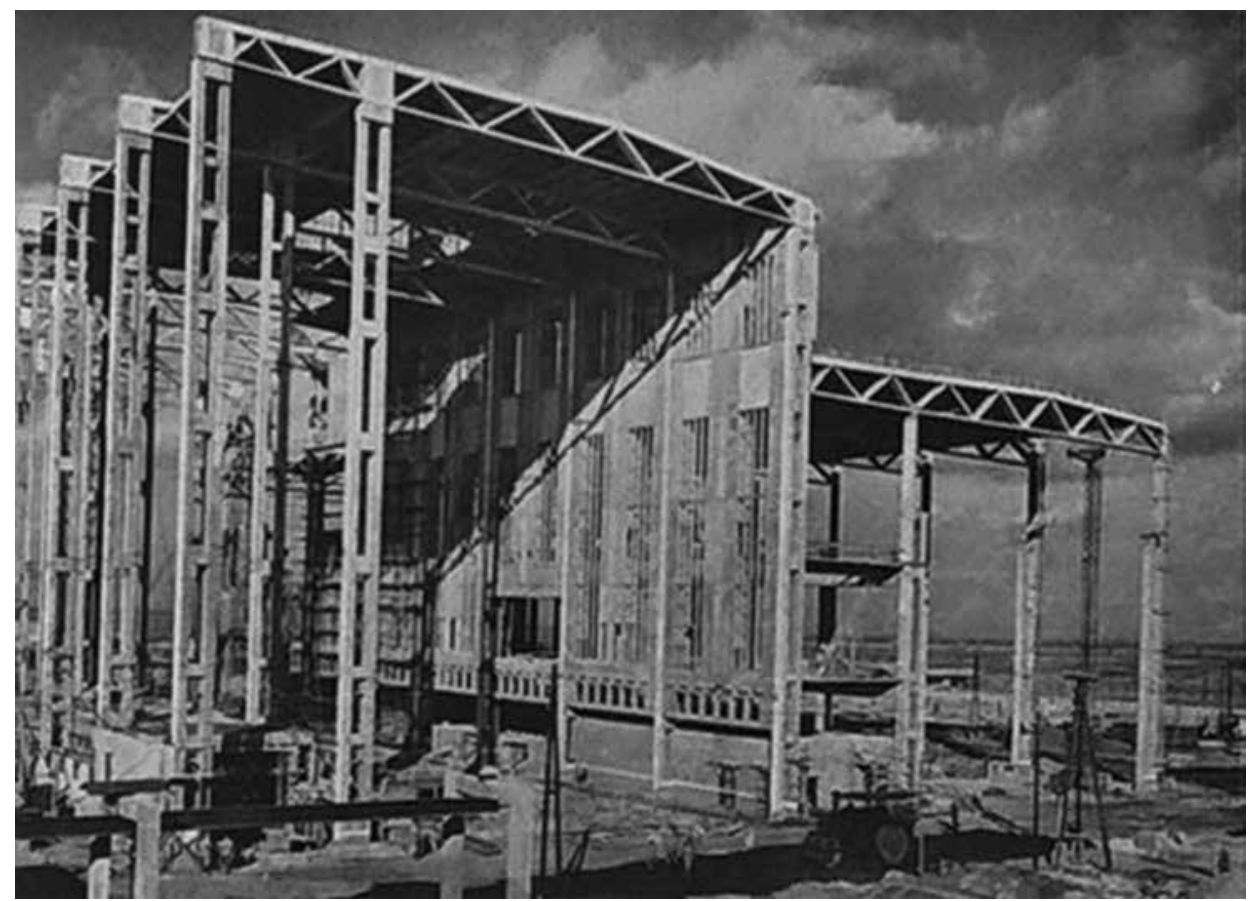

Figure 1. Thermal Power Station, Tiszaújváros (H) (Mátrai, Pászti, 1955) an example of the industrial buildings erected in the early fifties, using reinforced concrete and large-scale-on-site-prefabrication technic

marize some of the most important features of the development of Hungarian shell architecture after WWII.

It (re)started late, built examples had been few (even, or especially, compared to other countries of the eastern block) and industrial application remained predominant. The role of prefabrication, both as a rival in the form of common-and-economic column and beam systems (Fig. 1) or as a construction method had more significance in both the rise and the fall of shell architecture in Hungary, than in the Western World.

We created the exhibition 'Frozen Modernity - Heyday of Hungarian Shell Architecture' $^{2}$ in order to shed light on the largely forgotten achievements of Hungarian architects and engineers in the field of concrete shells after WWII. The exhibition cited international examples along the Hungarian structures in order to outline the architectural context of the period ranging from 1948 to the 1970-s - and to provide insight into the knowledge transfer between East and West during the socialist era.

\footnotetext{
${ }^{2}$ Presented at FUGA Budapest Centre for Architecture between 5 and 24 May 2016.
} 
The present paper focuses on the relation between the development of Hungarian shell architecture and industrialization with frequent references to prefabrication. The Hungarian efforts in the field of prefabrication (not restricted to shells) were internationally acclaimed ${ }^{3}$ - although, this special interest was partly given to the 'exotic'. Prefabrication, as an industrialized form of construction could and did serve as a direct manifestation of modernist ideals and it rapidly evolved after WWII in the Western World as well. The different social, economical and political context, however resulted in a different development considering its pace and areas of application in the Soviet sphere of interest.

The international trends of shell architecture are briefly outlined, considering the role of economy, publicity and formal quality in its rise and fall. A periodization is proposed, focusing on the built examples rather than on theory. ${ }^{4}$

The evolution of Hungarian concrete shells is discussed following this periodization. The economy of shell building and (because of its special relevance in Hungary) to some extent prefabrication is studied considering the special circumstances of a socialist economy.

A case study is presented. The KÖFÉM Factory, Székesfehérvár (1959, designed by István Menyhárd, Ipoly Farkas, and Lajos Semsely) is a cast-in-situ shell with double curvature, one of the first (!) to be realized after WWII. The inventive scaffolding and formwork applied to it resulted in a constructional method comparable in both time-consumption and cost to prefabrication. Following a brief description of the structure, its further evolution is discussed. The shells of KÖFÉM Factory became a frame of reference in Hungary, both figuratively and through its numerous later adaptation. International examples are cited, highlighting both the common and unique features of western and Hungarian shell architecture.

Both shell architecture and prefabrication in Hungary has its own legends regarding its international reception. The survival of these legends is largely based on the fact that with restrictions on travelling abroad and importing western publications the majority of the Hungarian engineering community was isolated during the socialist era, their primer source of knowledge being the second-hand information found in inland publications. Since both the history of prefabrication and shell architecture in the $20^{\text {th }}$ century have been somewhat neglected, these legends have never been questioned - and became the frame of reference. In an effort to have a more objective view on the matter, some key international references are analysed along with a brief summary of the possibilities and methods of knowledge transfer during the period of the Iron Curtain. ${ }^{5}$

\footnotetext{
${ }^{3}$ Attested by the special mention of the Auguste Perret Prize, received in 1961 by the collective of IPARTERV, state owned design office for industrial buildings, and a pioneer of on-site prefabrication. See below for further reference.

${ }^{4} \mathrm{~A}$ periodization based on the development of the theory of shell structures is presented in the pivotal work of Kurrer (Kurrer, 2008).

${ }^{5} \mathrm{~A}$ more elaborate discussion on the forms and characteristics of knowledge transfer is to be found in Gáspár, Sajtos, 2016.
} 


\section{ECONOMY OF SHELLS - INTERNATIONAL TRENDS}

Shells are economic - in terms of material usage. ${ }^{6}$ They carry their weights primarily through their form, rather than the sheer volume of the structure. This allows the designer to considerably reduce the material used, so far as he manages to find the optimal or at least suitable geometry. However, there are other factors contributing to the overall cost of the structure, such as the cost of design and construction (formwork, labour, etc.). In a market-driven economy these factors create a balance, ultimately guiding the planning and construction of shells. The economy of shells had a more decisive role in their development after the initial period, when the emphasis had been on the discovery of the possibilities of a new material.

We propose the following periodization for the discussion of shell architecture: the early, pioneering period ranging from 1920 to WWII, followed by the heyday of concrete shells from the end of WWII to the mid-1960s and the late period, after 1968 (Fig. 2).

Shell architecture began in the 1920-s, but until WWII, though theory had evolved rapidly, built examples had been the work of few, outstanding designers of this new field (among others Ulrich Finsterwalder, Franz Dischinger, Eduardo Torroja, Nicholas Esquillan, Pier Luigi Nervi) world-wide. Through the pioneering works of István Menyhárd, some remarkable structures (by international standard) had been built in Hungary as well. It is notable, that even though in the heyday of shells ranging from the end of WWII to the end of the sixties many architects and engineers had

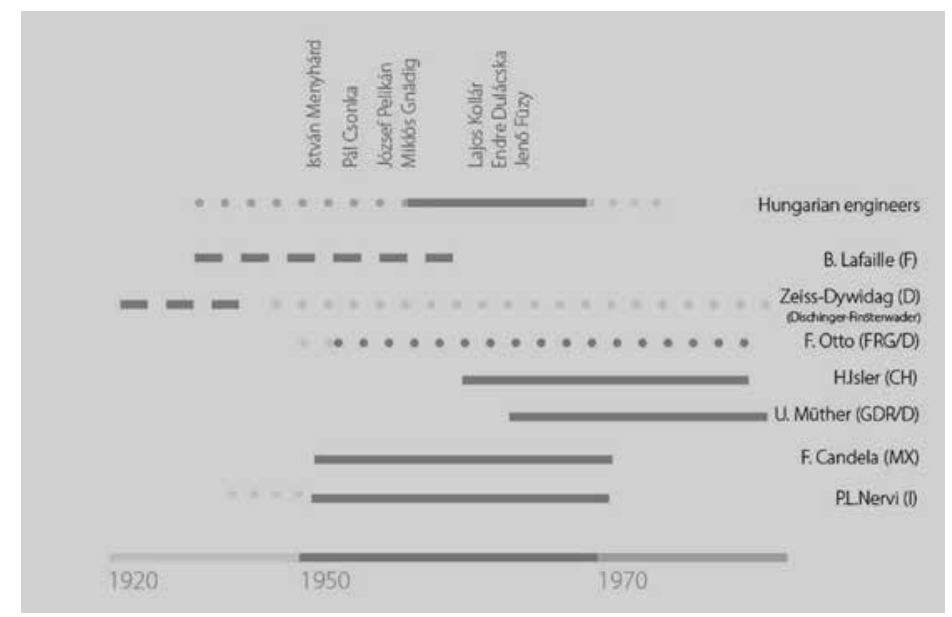

Figure 2. Proposed periodization of shell architecture, listing the activity of notable international designers along with the Hungarian developments. The diagram visualizes the parallel developments, and its intensity

\footnotetext{
${ }^{6}$ Recent studies (Végh, 2011) show, that shells are one of the most environmentally friendly structures due to their optimized material usage.
} 
been involved in the design of shells, shell architecture had been defined by relatively few individuals. A special, in most cases exclusive devotion to shells characterizes their work.

The early development of shell architecture was greatly influenced by the rapid industrialization. New building typologies were born, requiring larger spans - shells were most suitable. Their application was favourable, as steel was in short supply in most European countries after WWI, and reinforced concrete required less steel than a steel skeleton structure.

After WWII, the shock of the war resulted in extreme sensitivity to wasting material, which, together with the modernist idea of the desirable 'true form' (shaped by the internal forces) served as a solid ground for the development of concrete shells. The first period of their heyday in the western world resulted in their widespread application in industrial buildings. The 1960 Olympics in Rome can serve as a symbolical turning point in terms of their field of application. The first ever Games to be aired world-wide made not only athletes, but architecture into icons. Two major venues, both shells, and both designed by Nervi (the Palazzo [with Marcello Piacentini, 1959, Fig. 3] and Palazetto dello Sport [with Annibale Vitelozzi, 1957]) became symbols.

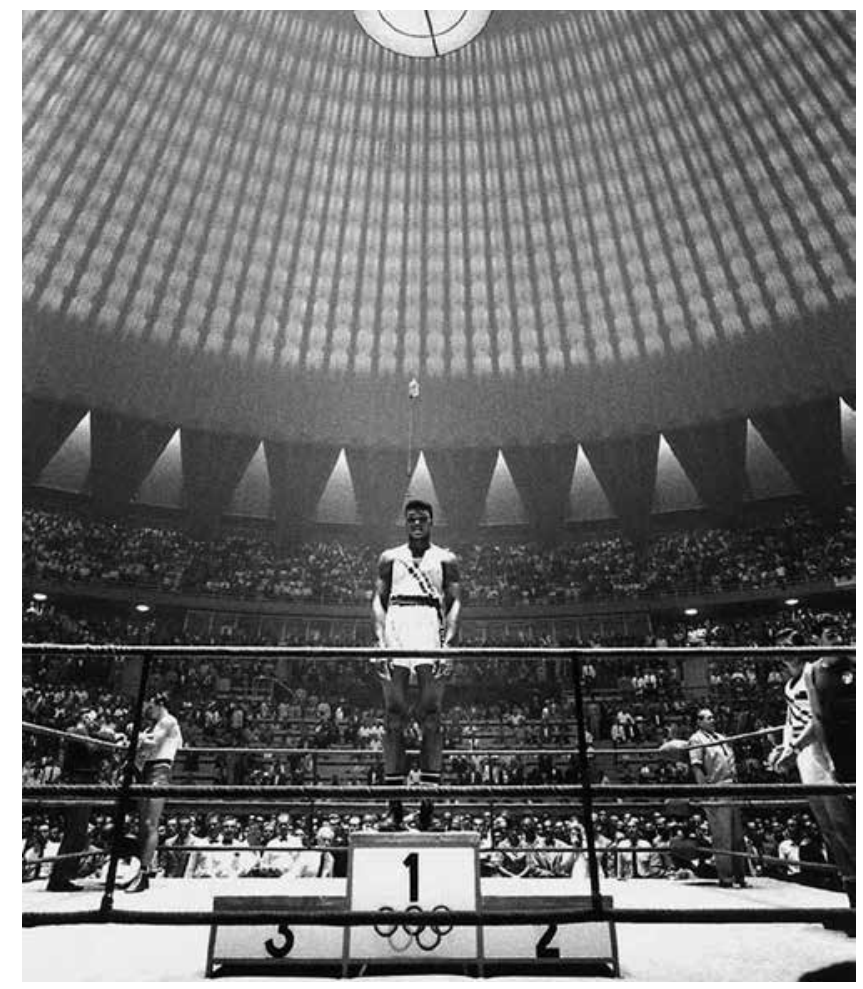

Figure 3. Medal ceremony in the Palazzo dello Sport, during the 1960 Rome Olympics 

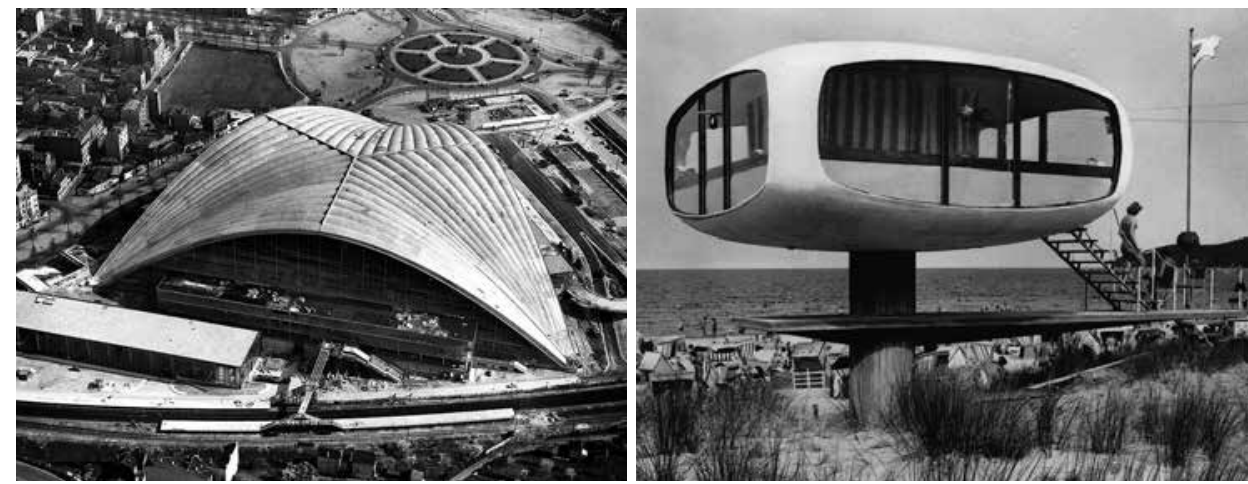

Figure 4. CNIT Paris (I), F (Esquillan, Camelot, Mailly, Zehrfuss, Prouvé, 1958) as Western, and Rettungsturm (r), Binz, D (Müther, 1968) as an Eastern example

By that time, even though extensive research had been done to reduce or optimize their excessive need of shuttering (either by prefabrication or by suitable geometries), it became clear, that due to the costly formwork and more complex, hence more expensive design process shells were not necessarily economic - for everyday use. The usual spans required for industrial application were in general not large enough, the gain in material usage could not compensate for the loss in terms of construction and design. Lightweight structures (steel and aluminium frame structures) became eventually predominant in the field of industrial application. The newly established popularity of shells, however, helped to boost a second period of heyday, where their most valuable asset became their formal quality. International modernism embraced shells as the new forms of a new era (Fig. 4). ${ }^{7}$

We have already referred to the ideological importance of industrialization of the building process as one of the cornerstones of modernism. The lack of skilled workforce after WWII was a common problem in Europe and a main argument for prefabrication. However, the economy of prefabrication is a delicate question - it depends greatly on the level of standardization (the higher the better). Even Nervi, who was an advocate for reinforced concrete, shells and prefabrication in the name of economical and aesthetical building, faced later on serious controversies (e.g. St Mary's Cathedral, Chiorino, 2011), indicating that, in case of highly individual buildings (or structures), prefabrication might not be the most cost-effective technique. $^{8}$

The criticism of modernism from the mid-sixties attacked among others its formal language. The development of concrete shell architecture was strongly linked to

${ }^{7}$ Felix Candela can be cited here, as being an emblematic idol of this era: although his primal sources of income were his more pragmatic designs for industrial halls, he became famous with his expressive church designs.

${ }^{8}$ In his above quoted lecture, Ove Arup reasoned against the standardization in general, considering it especially unsuitable to shells (Arup, 1957). 


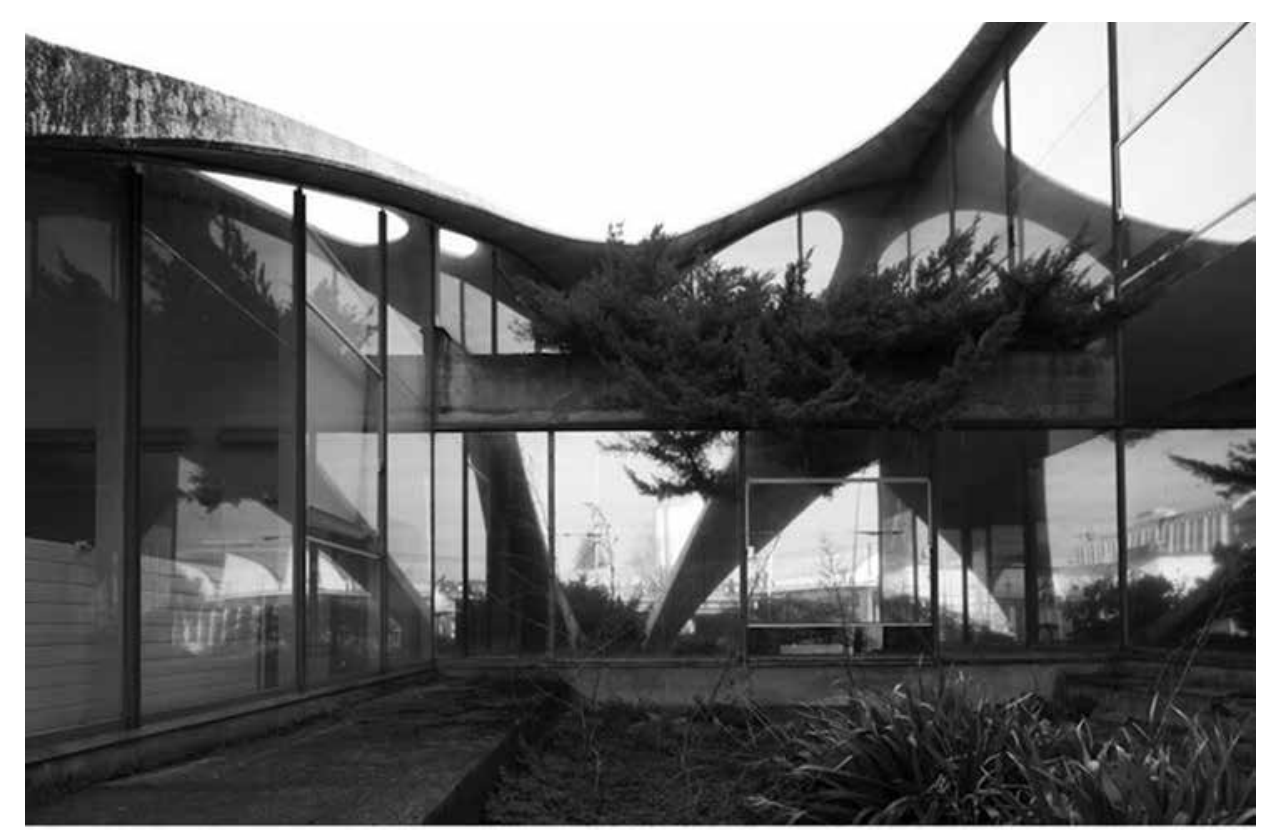

Figure 5. Pavillon Sicli, Geneve (Isler, Hilberer, 1969)

modernism early on, hence the fading of modernism resulted in the quick downfall of the era of shells. The legend of its economy was long gone, badly affected by the rising cost of labour, many of its masters had passed away, and their formal language gone out of fashion. However, the tradition of shell building has not disappeared: the same logic, a form driven by its internal forces characterizes the development of tensile structures which became popular in the late fifties and could reinvent itself numerous times ever since, even though it does have its limits of application and constructional constraints as well.

The architecture of Heinz Isler is a notable exception: he continued to build numerous concrete shells later on up to the eighties. Beside his devotion to shells (a key element in the development of shells in general), the other possible explanation might be his richer formal vocabulary (Fig. 5), constituting his own formal language which can be regarded as individualistic, a general architectural approach of the second half of the $20^{\text {th }}$ century.

\section{HUNGARIAN DEVELOPMENTS}

Marking the early period of shell architecture in Hungary is the activity of the German Dywidag company from the early thirties and the first build projects of István Menyhárd. Dywidag consciously opened to the international market after its 

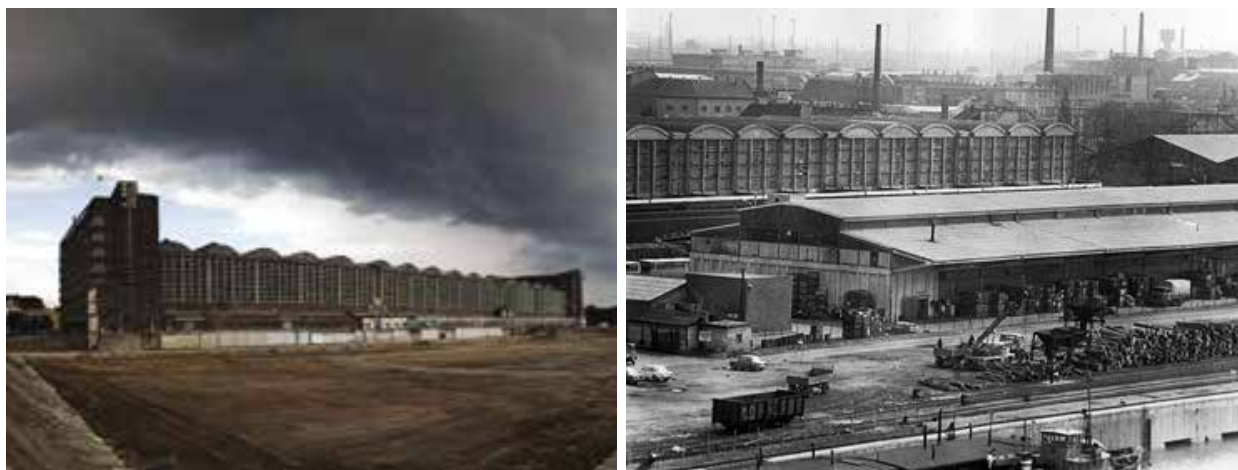

Figure 6. Frankfurter Großmarkthalle, D (I) in its present state and the Nagyvásárcsarnok, Budapest, H (r), archive

initial success at home. Their Hungarian projects can be seen as a more elaborate, inventive adaptation of their methods and systems (e.g. the Nagyvásárcsarnok [Dywidag in collaboration with Aladár Münnich, 1932, Fig. 6 right] as the bigger 'version' of the Großmarkthalle Frankfurt [1928], Fig. 6 left). Their early presence contributed to the decisive role of the German School in the theoretical and practical development of Hungarian shell architecture. The German tradition, an analytical approach as opposed to the more intuitive approach of the Italian or Spanish designers, however, already had its roots in the educational system of Hungary, a former member of the Austro-Hungarian Monarchy.

The early developments of shell architecture in Hungary were comparable to those in Western Europe, with projects having a strong affiliation to the most up-to-date international trends (e.g. István Menyhárd's first hypar shells built from 1938 onward, following the publication of their theory by Aimond in $1936^{9}$ [Aimond, 1936])

After WWII, Hungary became part of the Soviet sphere of interest. This, and the extreme shortage of timber within the newly established borders resulted in a different evolution, despite the somewhat common grounds, not only to Western Europe, but to other members of the eastern block.

In socialist economies, where prices are state controlled, material savings achieved by prefabrication or by the application of suitable structures (shells) have more relevance (Mokk, 1960). Further on, socialist ideology saw industrialization and by extension prefabrication as the most suitable tool for the new society. In this context, prefabricated shells are the perfect match.

The need for standardization in case of prefabrication was obvious. Standardization improved the economy of shell building in terms of reusable formwork as well. The state-driven, forced industrialization generated a constant need for new industrial buildings, where standardization was possible (Rühle, 1957).

\footnotetext{
${ }^{9}$ Menyhárd was in fact among the first ever, to build hypars. Around the same time realized Giorgio Baroni (Melaragno, 1991) in Italy and Ferdinand Aimond (Espion, 2016) in France their first hypar designs, based on Aimond's theory.
} 
This explains the vast number of shells built in socialist countries after WWII (especially Poland, CSR), the relative high level of prefabrication applied to them, and the predominance of industrial application. ${ }^{10}$ Since modernism and socialist ideology shared an enthusiasm for prefabrication and shells as extremely efficient structures, these efforts were usually recognized by Western publications - however, side notes were almost always elaborating on the economy of such structures, concluding, rightly, that it was a direct result of the broken balance of a socialist economy.

The acceptance of the formal language of shells as part of the architectural vocabulary for public buildings became later in the soviet sphere of interest: socialist realism formally detested modernism, explaining the time shift of almost a decade between the eastern and western heyday of shells, as icons (Baudisch, 2013).

The shortage of timber made the construction of shells in Hungary practically impossible, partially explaining that almost no shells had been built for a decade after the war - unusual in the eastern block. The state-dictated efforts in the field of prefabrication, however, were doubled: hence the first built shell-like structures were prefabricated. Shell-like, because with such exceptions as for example the cooling towers in Debrecen and Ajka (Fig. 7 left), they were mostly parabolic shells with ribs, with a single curvature - notable example is the salt warehouse in Kazincbarcika (Fig. 7 right). This meant, that their structural behaviour was mainly 2D - similar to an arch, while the true advantage of shells is that they can act as 3D surfaces, best exploited in case of double curvature.

The eventual revival of shells in the early sixties can be interpreted as the fortunate coincidence of the following factors:

- to some extent, the personal ambition of István Menyhárd, by that time an established expert in Hungary ${ }^{11}$ within the field of shells, who argued more and more vehemently (Menyhárd, 1960) that a well-designed, cast-in-situ doubly-curved shell can be just as economical as a prefabricated roofing for industrial application. When he became chief structural engineer of IPARTERV (state-owned design office for the design of industrial buildings) in 1957, he could finally make his case.

- the shift toward the formal language of modernism following Stalin's death, characteristic of the whole eastern block.

- the activity of a new generation of engineers and architects, the first who either worked with or studied from and was greatly inspired by the pioneers

\footnotetext{
${ }^{10}$ According to Rühle, in both Poland and the CSR specialists working in state-controlled design offices were responsible for the development of a range of typologies, with possible field of application and basic structural analysis. These standardization efforts were meant to induce the wider application of shells by simplifying the otherwise complicated design process.

${ }^{11}$ The shortage of timber forced Menyhárd and other leading experts of shells to busy themselves with the theory instead of practical design. Menyhárd held the first regular course on shell structures in Hungary for the postgraduate structural engineers after WWII. His course became legendary. It was his close colleague Elemér Bölcskei, who later with the assistance of Árpád Orosz introduced the course on the theory of shells to the regular curriculum of structural engineering.
} 

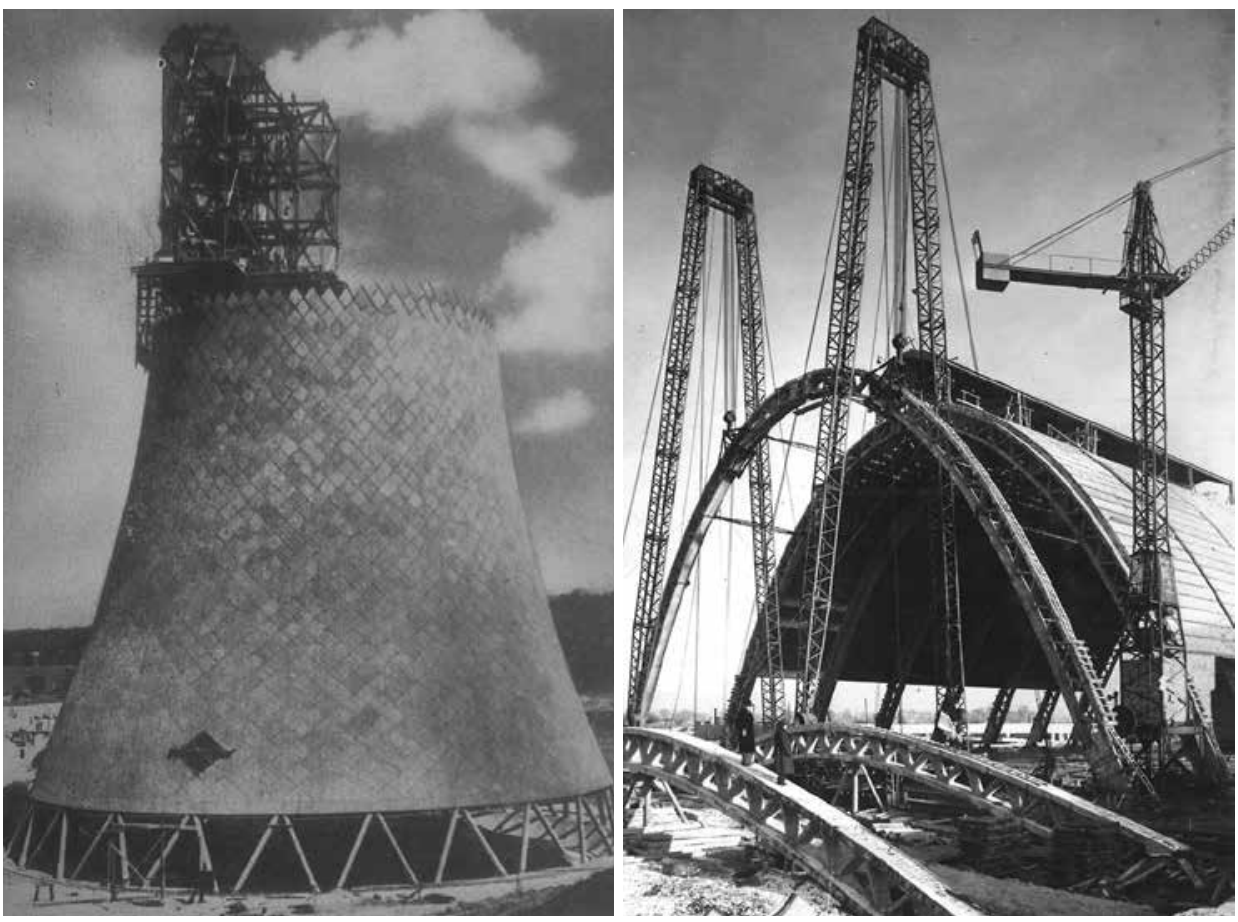

Figure 7. Cooling tower, Ajka, H (Mátrai, Pászti, 1951) (I), Salt warehouse, Kazincbarcika, H (Gnädig, Horváth, 1952) (r)

of pre-war shell architecture in Hungary, foremost Menyhárd, Pál Csonka and József Pelikán ${ }^{12}$ (the latter two especially in the field of theory and education).

While there were locally important innovations during this period supported by the unquestionably remarkable theoretical work of Hungarian engineers, shell architecture in Hungary could be interpreted as the later resonance of Western trends which, in itself attests to the fact that the isolation behind the Iron Curtain was relative.

Although their heyday started late in Hungary, their fall occurred quite the same time, around the seventies - for quite the same reasons as in the west: the development of constructional technics, the higher cost of labour along with the new, more realistic paradigm of socialist economy superseded their (industrial) application while they failed to become real part of the formal language for more iconic projects which could have postponed their fate. The late period is characterized by two

\footnotetext{
${ }^{12}$ Kázmér Szmodits, probably lesser known internationally, also contributed significantly to the early developments of shell theory in Hungary (Szmodits, 1953). As a city council official, he studied the plans of the Great Market Hall submitted by Dywidag, and later became responsible for its restoration (the roofing partially collapsed due to bombing during WWII).
} 

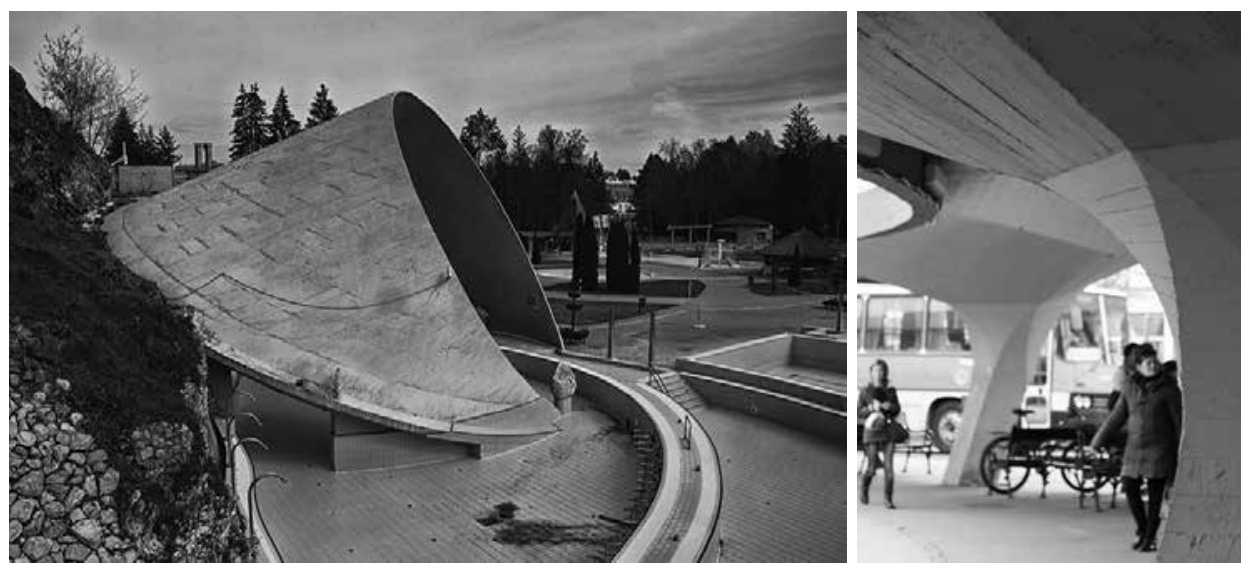

Figure 8. Thermal bath, Miskolctapolca, H (1972) (I), Bus station, Eger, H (1968) (r)

trends: the synthetizing approach reworked a former example using a more complex theory (as for example KÖFÉM II, see below.). The formerly unseen expressive formal language of some of the late shells constitutes the other trend. In these rare cases architects took the initiative, inspired by the formal possibilities of reinforced concrete - as with the sunshades of András Zsuffa (MÉLYÉPTERV, in collaboration with Gyula Márkus, ${ }^{13}$ structural engineer, e.g. Fig. 8 left), or some of the more expressive shells by architect János Dianóczky (UVATERV, in collaboration with Dezső Detre, structural engineer, e.g. Fig. 8 right).

\section{KÖFÉM FACTORY, SZÉKESFEHÉRVÁR (1960)}

By the mid-fifties, the ideologically induced, but economically unsubstantiated prefabrication based on large, on-site prefabricated elements combined with a low-level of mechanization faced more and more critique within Hungary. One of the leading figures of the 'opposition', was István Menyhárd (Menyhárd, 1960). He proposed to challenge the economy of the somewhat megalithic structures of prefabricated industrial halls with cast-in-situ shells.

He joined the team of IPARTERV in 1957 as a chief structural engineer. Contemporary sources (Erényi, 1990) claim that he was asked to take this position, in order for IPARTERV to broaden its possibilities in structural solutions keeping up with the changing needs of the socialist economy.

His first major assignment was the roofing of a large industrial hall, $270 \mathrm{~m}$ long, 60 wide with double aisle for the KÖFÉM Factory in Székesfehérvár (Fig. 9), an aluminium-processing plant.

\footnotetext{
${ }^{13}$ Gyula Márkus' handbook, on the theory and calculation of rotation-symmetric shells (Márkus, 1978) became a practical reference for engineers both inland and abroad.
} 


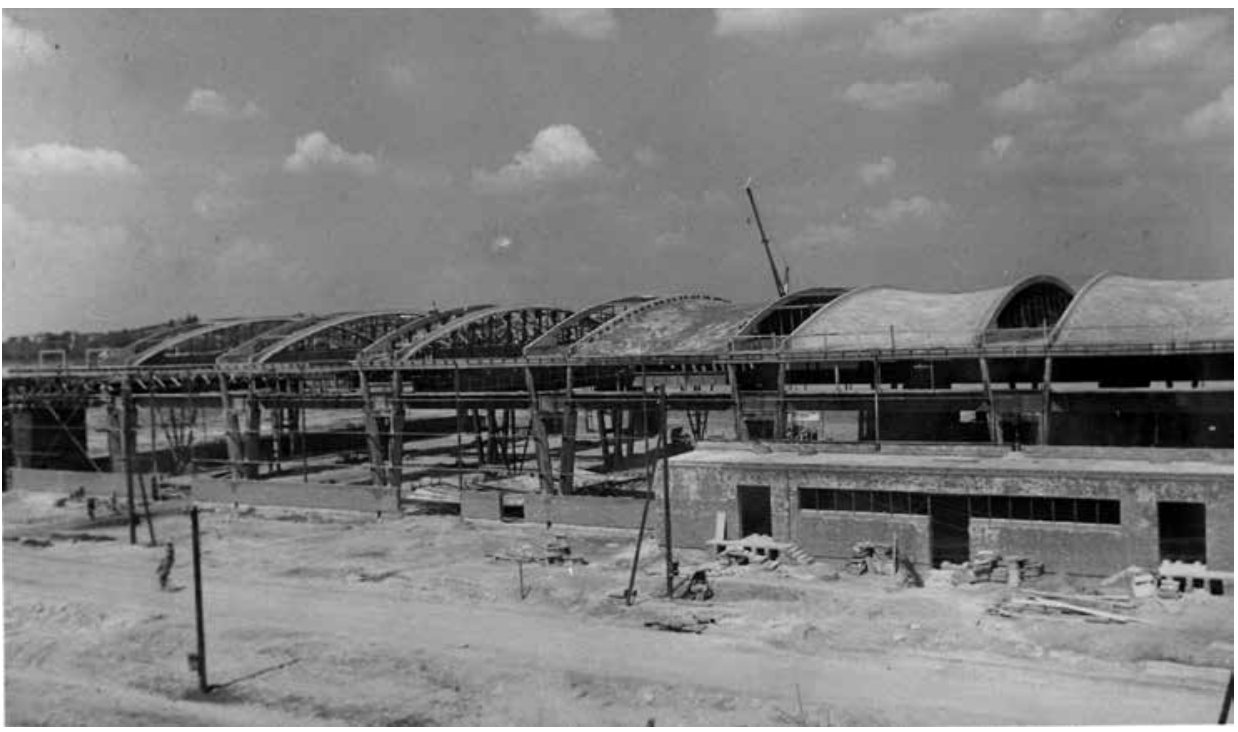

Figure 9. KÖFÉM factory during construction

In the initial phase, several alternatives were drawn up (Erényi, 1990), eventually, Menyhárd decided to develop a structure consisting of successive, slightly inclined parabolic arches with a composite shell spanning between every other pair. Composite in the sense that the shell constituted of a hypar connected to two conoids providing a horizontal edge along the perimeter of the building, which was most favourable regarding drainage. The lighting was provided by clerestory glazing, formed between the parabolic arches and the horizontal section above the columns, incorporating the tie-rods. The system structurally can be interpreted as a series of
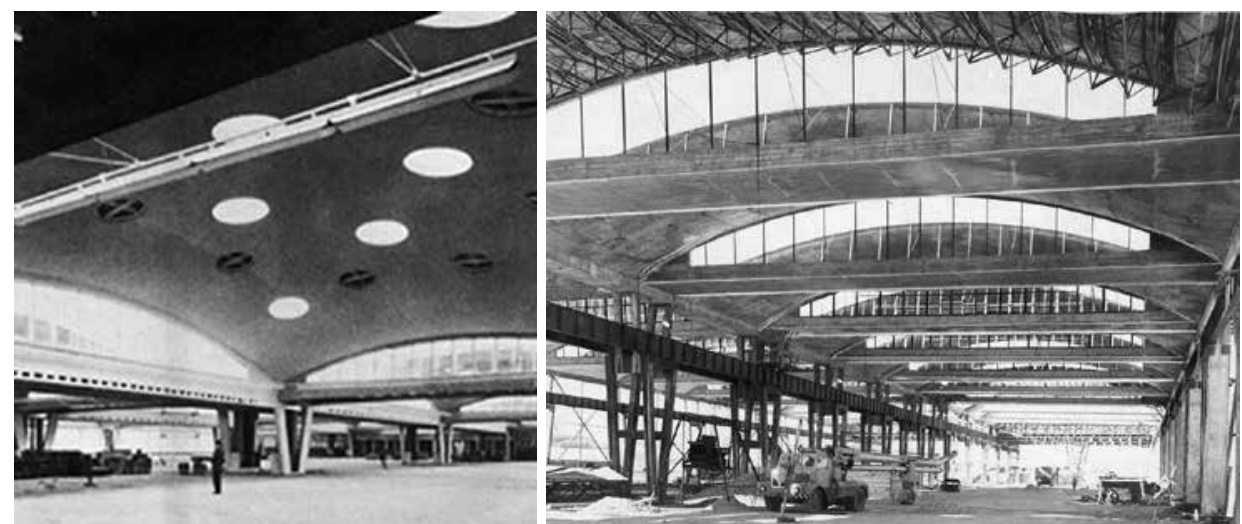

Figure 10. Brynmawr rubber factory, GB (I) and KÖFÉM factory during contruction (r) 
tied-arch bridges consisting of two parabolic arches and tie rods (the horizontal sections as a hanging deck), spanning between them the hyperbolic shell surfaces.

This interpretation helps to connect the system adapted to KÖFÉM Factory (Fig. 10 right) to the earlier works of Menyhárd. Before WWII he designed a number of bridges, refining the system of tied-arch bridges in the thirties. His first major commission, built in 1941, the Bus garage in Kelenföld, a major achievement in the field of reinforced concrete shells at the time, also benefited from his earlier experience in bridge-design. He was inspired by the 40m-span Nagyvásárcsarnok in Budapest, designed by Dywidag in 1932, but he considerably developed its system. The $86 * 100 \mathrm{~m}$ building of the bus garage was covered with a series of elliptical shells, only $6 \mathrm{~cm}$ thick, resting on shallow parabolic arches, spanning more than $90 \mathrm{~m}$. The tie-rods were installed underground. This reinforced concrete structure was the largest of its kind at the time of its erection.

Beside Menyhárd's own earlier projects, the roofing system applied to the KÖFÉM Factory shares remarkably many features with the Brynmawr Rubber Factory (1950, structural designer Ove Arup, Ronald Jenkins, Fig. 10, left [Arup, Jenkins, 1953]). ${ }^{14}$ The principle of the ' $\mathrm{V}$ ' shaped column supporting two neighbouring fields reappears at KÖFEM (here prefabricated), just as the arches with tie-rods, acting as edge beams ${ }^{15}$ and the clerestory glazing, a principal source of natural light. Menyhárd initially favoured the hypar surface to an elliptical surface (as the shallow domes of Brynmawr), for two reasons: in case of a hypar, in the principal direction of positive Gaussian curvature compression occurs, and in the other tension, making it stronger against buckling compared to elliptical surfaces. Its straight generatrices, allow for the use of straight elements in the formwork. ${ }^{16}$ Furthermore, the hypar of the KÖFÉM Factory is a translational surface - this quality proved to be the most beneficial later on, as the main invention of the structure, its constructional technique had been developed.

The proposed structural system had been quickly accepted by the leaders of IPARTERV as both architecturally pleasing and feasible, but the development of a suitable, efficient and economical constructional method was cumbersome. In order to keep up with the tight deadline projected for construction, considering the possibility of 'serializing' the construction of the identical units along the hall, they proposed a reusable, moveable formwork-system together with demountable scaffolding for the roofing, and on-site prefabricated columns. The project faced major

\footnotetext{
${ }^{14}$ The Brynmawr factory was in fact published in Hungarian as well, for example in Magyar Építöipar (Harasta, 1959).

${ }^{15}$ Jenkins in answering a question about the reason for the straight clerestory glazing as opposed to an inclined solution claims their solution structurally more feasible - since the edge beam requires only vertical support. In case of the KÖFÉM factory, however, due to the different shell geometry applied, the inclined arches are beneficial: the thrusting required from the shell spanning between the arches results in compression in the shell normal to the arches which counteracts the tension generated by the vertical loads, and hence reduces the overall value of stresses. (Arup, Jenkins, 1953)

${ }^{16}$ However, at the end, they did not exploit this property of the hypar, because the primal consideration was given to the scaffolding, and the applied technique made such formwork superfluous - see Fig. 10.
} 
difficulties such as overwhelmingly limited time for planning, the catastrophic results of the careless construction of the full-scale mock-up of one unit which made the realization of the proposed solution uncertain. Eventually, Lajos Semsey came up with an inventive constructional system that made full use of the special circumstances given in many industrial halls: that it would be equipped with an overhead travelling crane. The runways were mounted onto the columns prior to the erection of the arches and the shells. The bridge crane provided a mobile ground for the easily demountable formwork and scaffolding for both the arch-girders and the shells, which were erected separately, first the arches, followed by the shells. The greatest advantage of the translational nature of the hypar was that it allowed for the application of identical formwork-elements of the size of $1.6^{*} 11 \mathrm{~m}$. This significantly simplified both the formwork and the necessary scaffolding, and made the whole system very cost-effective. In fact, the constructional technique applied to KÖFÉM Factory was said to be $25 \%$ cheaper compared to any other technique, including prefabrication.

Two typologies had been developed based on the KÖFÉM Factory during the heyday of shells: the tube manufacturing hall for the Csepel Factory (1962, Fig. 11 right) and a new hall for the GANZ MÁVAG Factory (1965, Fig. 11 middle). While both concepts originated from Menyhárd (structure) and Semsey (construction), they have been developed by Róbert Reisch and Csongor Horváth, respectively. In both cases, the construction was based on the same principle, the moveable and reusable scaffolding mounted onto the bridge crane.

The development in case of the hall for the GANZ MÁVAG factory was focusing on the reduction of the ' $\mathrm{V}$ ' columns to regular columns, which were easier to produce and assemble. The translational, hypar surface spans over $9 \mathrm{~m}$ between two 19-m-parabolic arches with different heights - due to the reduction of the column they are placed above each other. Natural light is provided via clerestory glazing framed by the arches. The system is completed with tie-rods. This solution resulted in a - though formally richer - quite typical roofing with north lights, which made it an exciting but somewhat exaggerated experiment, a dead-end in the development of this typology.

The earlier design of the tube hall for the Csepel factory, however, became one of the most successful reinforced concrete shell roofing typology of the era in Hungary, with approximately 10 successive applications, with more than $60000 \mathrm{~m}^{2}$ of indus-
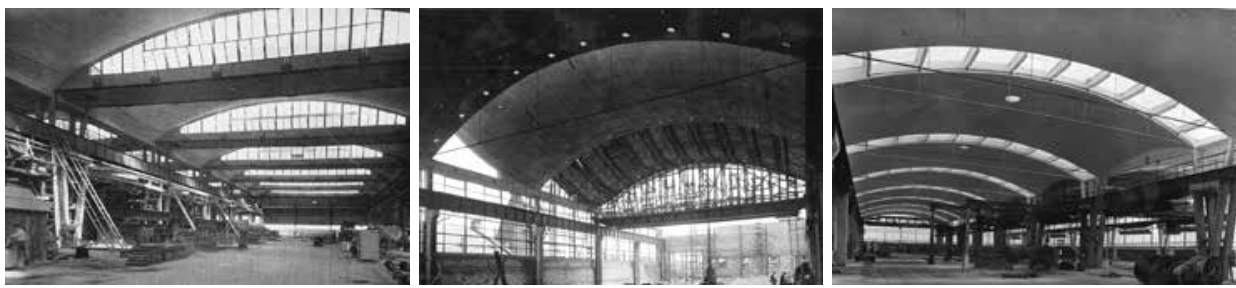

Figure 11. Evolution of the KÖFÉM typology: The KÖFÉM (l), the MÁVAG (m) and the Csepel tube hall (r) 

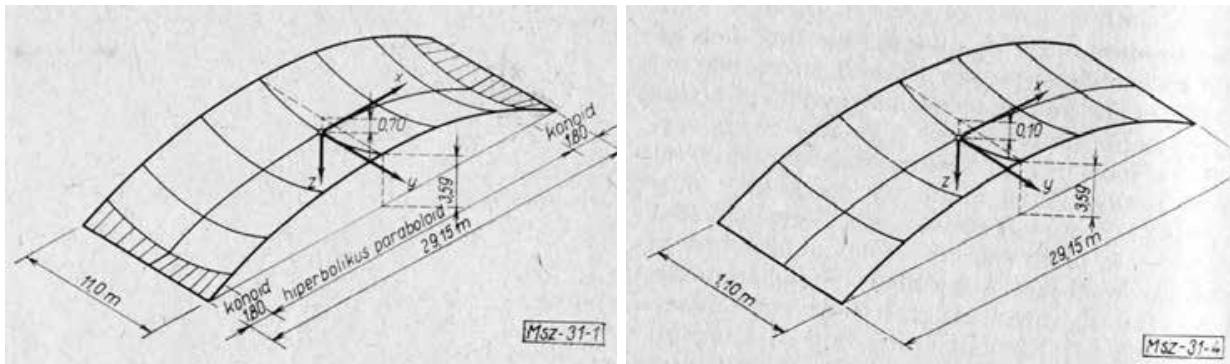

Figure 12. Comparison of the geometry of the shell roofing for KÖFÉM I (I) and II (r)

trial halls covered overall. While the application and role of the ' $\mathrm{V}$ ' shaped columns are the same as they were in Székesfehérvár, both the curvature of the shell and the lighting is substantially changed. The shells of the tube hall are also translational surfaces, but elliptical and the fields over the columns are not lowered (omitting the clerestory windows), but kept in-line with the edge of the shells. The arch-girders hence provided natural daylight as skylights. The popularity of this typology is largely due to its extreme efficiency considering the time of construction: the erection of the shells from start to lowering the formwork took only 5 days per unit (spanning over $14 * 22 \mathrm{~m}$, each).

The synthetizing approach of the late period of shell building is noticeable in the later developments of the KÖFÉM-model. Lajos Kollár and his colleagues' design for an additional, in both structure and layout similar hall to Menyhárd's design for KÖFÉM (KÖFÉM II, Fig. 12 right) can be deduced as an adaptation of a more refined theoretical model to the original concept (Kollár, 1969). By applying the bending theory, instead of membrane theory, they managed to maintain the overall form with the horizontal edges, while creating a single surface, a hypar of the fourth-order. Kollár and his colleagues took advantage of the most up-to-date computational techniques - at the time of the design of KÖFÉM I it would have been hardly possible to make the calculations based on the more complex model of bending theory.

However, it is noteworthy, that almost 10 years earlier, IPARTERV had already solved the problem of a single hypar surface with two parallel horizontal edges. Miklós Gnädig, with whom Lajos Kollár collaborated numerous times from 1954 on, designed for the shell roofing of small prefabricated elements of the Újpest Tannery (1954, Fig. 13) a hyperpolic-parabolid of the fourth order also, where the varying height of the hypar (between 0 and $75 \mathrm{~cm}$ ) allowed for horizontal edges on both sides. Although not much is known about the applied theory at the Tannery, an assumption can be made based on Gnädig's more detailed report of the salt warehouse in Kazincbarcika, designed two years earlier (Gnädig, 1956): When describing the structural model of the supporting walls (fourth-order surfaces), he hinted, that the geometry allowed for the application of membrane theory. 


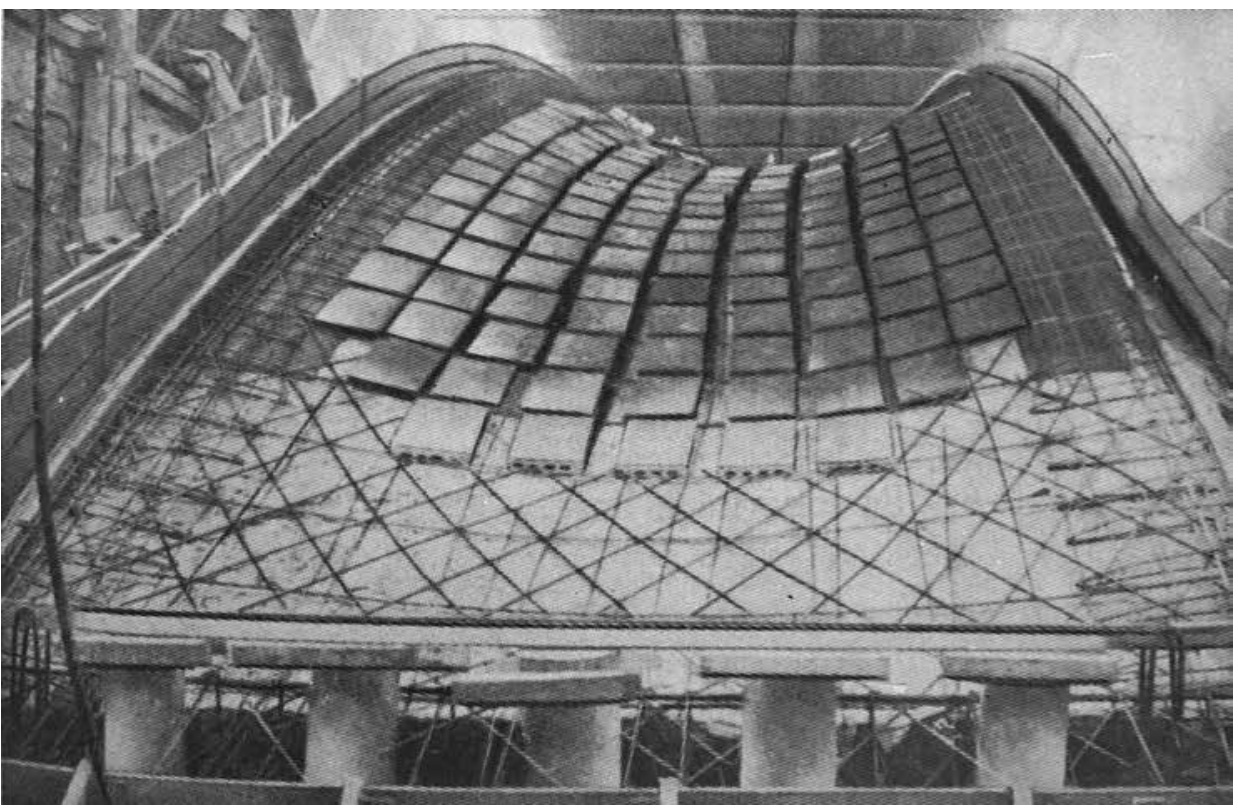

Figure 13. Újpest tannery, during construction

The prefab factory near Manchester (designed by Taylor\&Young, Galantay, 1956, Fig. 14 right $)^{17}$ is an interesting international example to study along the KÖFÉM Factory, especially considering their formal similarities and different constructional approach. While their size is almost the same (the single span of both structures is around $30 \mathrm{~m}$ ) and they share such features as the ' $\mathrm{V}$ ' shaped columns and the changing fields of translucent and solid, their structural behaviour is quite different. While the cantilevering arches support the skylights at Manchester, hence acting as the primer structural elements, the parabolic arches and the shells spanning between them at the KÖFÉM Factory work as a complex system, without such hierarchy (the shells work against the lateral buckling of the arches and transmit horizontal forces). While both the arches and the shell segments had been cast-in-situ in case of KÖFÉM Factory, the arches of Manchester were assembled on the ground from prefabricated elements and then lifted to their places vertically, while the columns were erected piece-by-piece. The construction method applied to the Újpest tannery is comparable, although, in that case the pre-assembled shells had to be moved both vertically and horizontally (with the use of a basic track system).

A last application of the KÖFÉM-model was another hall for the Csepel factory (1967, Fig. 15 left), which, besides being another example of the synthetizing approach of the late period, can be seen as another rework of Brynmawr Rubber

\footnotetext{
${ }^{17}$ It was published in AA in 1956, and later in Mokk, 1960. AA was subscribed by IPARTERV.
} 

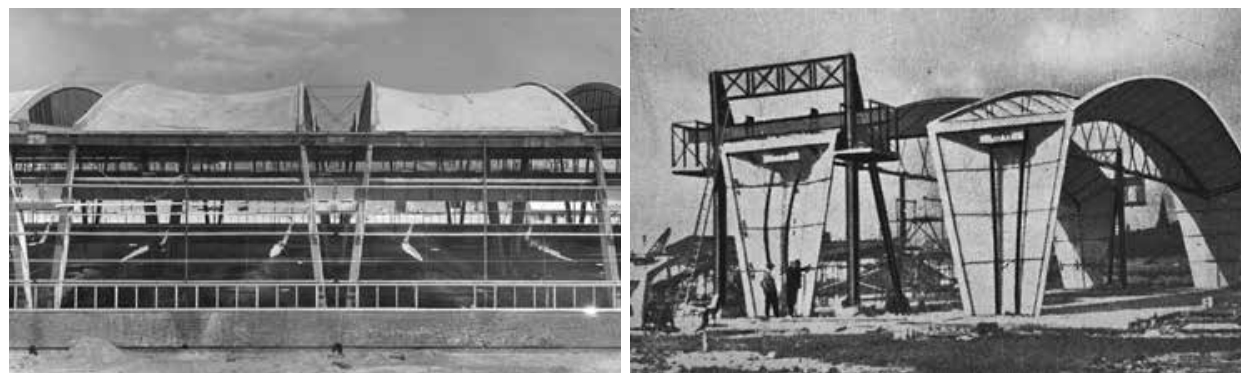

Figure 14. KÖFÉM factory (phase I) (I) and Prefab factory near Manchester, GB during construction (r)
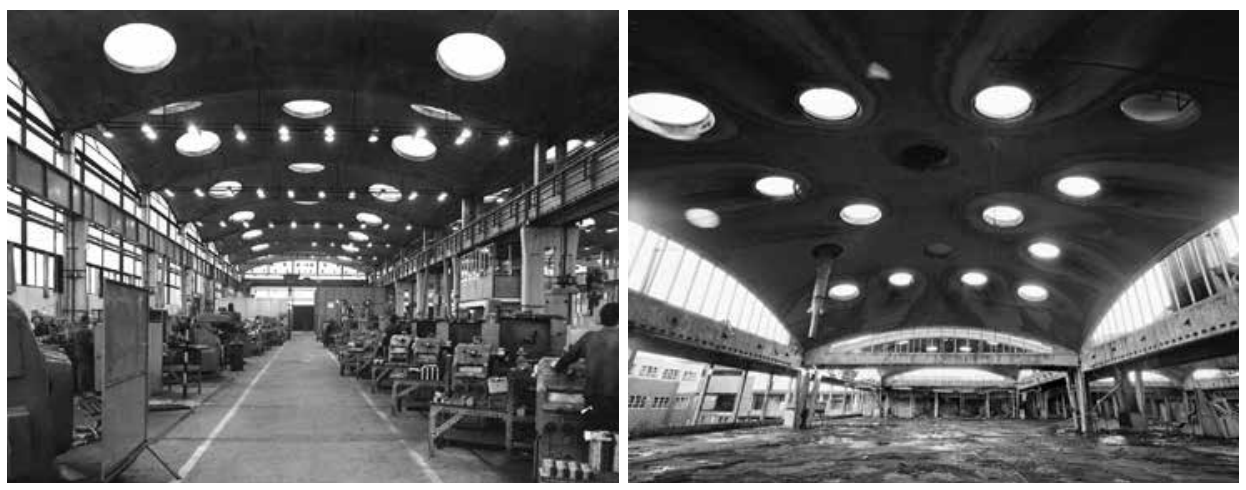

Figure 15. Csepel factory hall (1967) (I), archive and Brynmawr Rubber Factory (r), prior to its demolition showing signs of leaking around the skylights

Factory. As opposed to the more theoretical approach of the KÖFÉM II, the motivation was to further simplify the structural system of the extremely succesfull Tube Hall, making its construction even more efficient. The structural engineer was Róbert Reisch, who worked along with Menyhárd on the tube hall-typology earlier.

The geometry of the shell surfaces was quite similar to the Tube Hall, an elliptical translational surface, but instead of the ' $\mathrm{V}$ ' shaped column, Reisch opted for the regular column, and hence the edge beams between two neighbouring shell units became too thin to incorporate a skylight. He adopted the circular skylights of the Brynmawr factory - arguing that, besides providing excellent lighting, it makes the system most flexible (both the number and the size of the skylights can vary). ${ }^{18}$

Despite the unifying approach, the system's basic characteristics remained: the shell and its edge beams (however thin) had to be constructed in two steps. The constructional deficiencies of the circular skylight had not been solved entirely. The leaking is an acute problem until today, just as it was in the case of Brynmawr.

\footnotetext{
${ }^{18}$ More detailed study of the effect of constructional details such as insulation, waterproofing can be found in Reisch, 1972 and Erényi, 1990.
} 
It was realised in 1967, and became one of the last Mohicans of the era of shells in Hungary - especially their industrial application. Reisch, an advocate of Hungarian shell architecture ${ }^{19}$ published his design in 1972 in an attempt to resume the discussion of the efficiency of shells, but the advancement of lightweight structures made it into a swan-song of an era of remarkable engineering.

\section{ECONOMY OF THE EXOTIC - WESTERN RECOGNITION}

It was ideologically favourable during the socialist era to (selectively) use the international feedbacks to prove the Hungarian developments equal to, or superior to their western counterparts. The presented brief summary along with the case studies highlighted the fact that, despite the undoubtedly innovative approach of Hungarian engineers and architects, shell architecture in Hungary could better be described as following Western trends than the other way around.

The described shells, even in their present, deteriorating state represent an important part of the architectural heritage of Hungary. Their message is relevant - even or especially, if this message is more local than suggested by the somewhat over-promoted international significance of the industrial architecture of the $20^{\text {th }}$ century Hungary.

The international fame of Hungarian industrial architecture is in many cases taken out of context. 'In Poland, where architectural iron curtain is thinnest (...)' is a brief yet enlightening remark from Robin Boyd (Boyd, 1958): Poland (and the CSR, or even Yugoslavia) had far better Western publicity than Hungary. Their presence was more noticeable. One of the cornerstones of the myth of the positive western recognition, the UIA (International Association of Architects) prize given to IPARTERV in 1961 is just as much the result of a very professional, and direct lobby supported by the new regime seeking validation both inland and abroad after 1956, as the true admiration of excellence.

The laureate of the UIA Auguste Perret Prize, given out for the first time in 1961 was in fact Felix Candela. IPARTERV received special mention ${ }^{20}$ for its continuous and persistent work in the field of on-site large scale prefabrication, ${ }^{21}$ along with the Architectural Department of the Ministry for Education of Great Britain for the development of the CLASP System. Moreover, the declaration of the Auguste Perret prize claimed it to be more of an encouragement to promising young practices or practitioners rather than an award of accomplishment (n.a. in AA, 1961). The Auguste Perret Prize (one of the 4 awards given out by UIA), honours the achievements related to technology applied to architecture. To award a practice that was

\footnotetext{
${ }^{19} \mathrm{He}$ presented at the annual Symposium of the IASS in 1965 in Budapest, his lecture was an overview of the developments of Hungarian shell architecture (Reisch, 1965)

${ }^{20}$ Special mentions were rare, in fact, in most cases only one laureate was named - and the list is truly illustrative, including among others Jean Prouve, Piano and Rogers, Werner Sobek and Shigeru Ban.

${ }^{21}$ Although the personal efforts and inventions, and to some extent the emerging architecture of this field were regarded with admiration, the concept was severely criticised for being extremely unsuitable to the unadvanced state of mechanization of the building industry in the Eastern Block (Haas, 1957, AR, 1960)
} 
focusing its efforts on industrial application and prefabrication seems to echo the still prevailing ideal of technological architecture of modernism - even, if the methods applied were not so much novel, but rather considered (despite being ideologically appealing), expensive in terms of cost and labour in the west.

By 1961 Felix Candela was famous, world-wide. He represented the new paradigm of shell architecture, turning from practical to iconic (e.g. Fig. 16). His works were often published in acclaimed international publications, such as L'Architecture d'Aujourd'hui (AA), closely linked to the UIA. IPARTERV's success, however, was only preceded by one single article in AA about the industrial architecture in Hungary in 1959, featuring major projects of IPARTERV (among others, the aforementioned Salt Warehouse in Kazincbarcika). By comparison, a complete issue was dedicated to Polish architecture, with regular features from the mid-fifties to 1961 on projects in CSR, Poland and Yugoslavia - focusing mostly on the developments in the field of industrial architecture and prefabrication, with an emphasis on the application of shells. In favour of IPARTERV ${ }^{22}$ was the very nature of a (well-organized) state owned design office that might have been appealing and strange at the same time in the socialpolitical context of the early sixties in Western Europe. The work they have done was

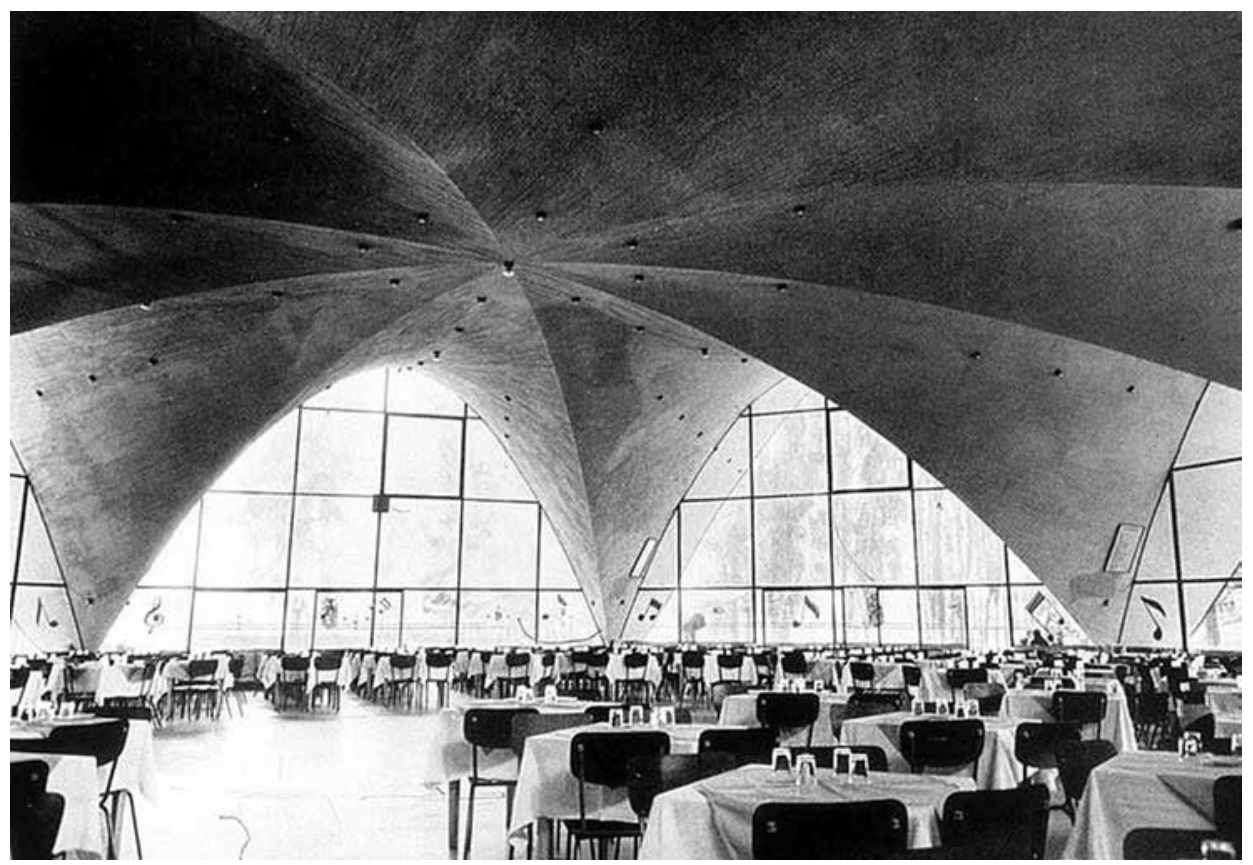

Figure 16. Restaurant Los Manantiales, MX (Candela, 1958)

${ }^{22}$ The presence of Máté Major (Head of the Hungarian Association of Architects) and Pierre Vágó (Hungarian expat) in the 6-head jury might have helped the case. The role of Máté Major, as an advocate for Hungarian modernist architecture both at home and abroad is controversial and deserves a more detailed study. 

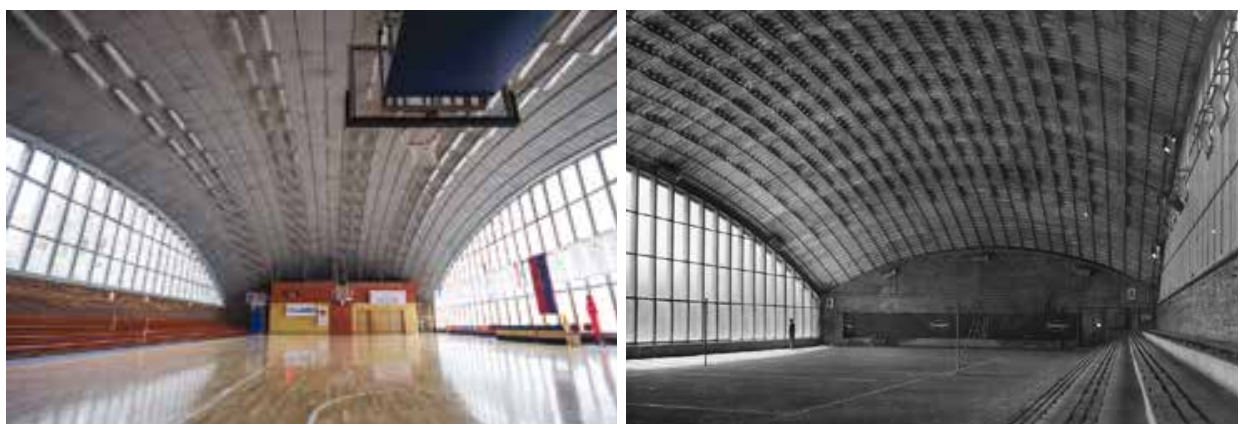

Figure 17. Vasas sports hall (aluminium shell), present (l) and original state (r)

coherent and of high technical and architectural standard and last but not least, they have pursued a very conscious PR activity abroad ${ }^{23}$ - even if its outcome was not to compete in volume with the publicity of architecture of other states from the eastern block.

We have already discussed the general approach of the West towards the term 'economic' in the Soviet Sphere of interest - considering it a result of the special characteristics of socialist economics.

In a short article in Architectural Review (n.a. AR, 1960), describing the VASAS sport hall (1957, with Szendröi, Papp, Fig. 17) designed by Menyhárd appears another aspect, vital in terms of the international recognition of Hungarian shell architecture: had it not been built or published so late it would have been considered very remarkable. ${ }^{24}$ Regardless of their formal quality or their technical ingenuity, shells built in Hungary were too late - they were not interesting any more, being, as they were, rational and practical. By that time, the international trends were searching for the extraordinary - a quality that was rather alien to the very pragmatic and analytical approach of the key figures of Hungarian shell architecture, mostly engineers.

\section{THEORY AND ARCHITECTURE}

The involvement of Hungarian specialists in the development of the theory of shells seems to be internationally more significant compared to the realized projects. ${ }^{25}$ Shell architecture is a special field, but theory and practice had separated

\footnotetext{
${ }^{23}$ Typical of the PR activity of IPARTERV was its refined graphical output - its importance was noted by AR praising the New Hungarian Quarterly (n.a. AR, 1963), a state-supported international publication in English - referring to an article on IPARTERV, by the way.

${ }^{24}$ See 'Appendix' for the full citation.

${ }^{25}$ Even though the existence of a Hungarian School in the theory of shells promoted by Stefan Polónyi might seem to be an exaggeration, especially in comparison to the German School - containing the ground-breaking and universally referenced work of Flügge, Dischinger, Finsterwälder, Föppl.
} 
relatively early on - in Hungary probably less, than elsewhere, but it was a general tendency. The refined methodology deduced from theory was often substituted with cruder, yet effective approximations - a vital instrument of practical engineering. ${ }^{26}$ The complexity of the applied theory had rarely had a decisive impact on the design - an illustrative example is the comparison of the KÖFÉM I. and II., where despite the major differences of the complexity of the models used, even a trained eye would not see much difference, in terms of architectural quality.

The pivotal work of Csonka, Pelikán, Menyhárd, Kollár, Endre Dulácska and later Tibor Tarnai, their active involvement in the international engineering community $^{27}$ is acknowledged world-wide. The term 'late', however, applies here as well. The international publication of scientific research done in Hungary during the socialist era was a difficult and lengthy project - even with their excellent international reputation. Most works (e.g. Csonka, 1970, Márkus, 1978) were published abroad long after the heyday of shell architecture (the theory of shells remained - and to some extent still is - an active field of research long after the heyday of shell architecture).

\section{ENGINEERING ROMANTICISM}

Working with shells is romantic: shells represent true forms - guided by their inner forces, a quality which is honoured in every movement with a touch of engineering. Their idealization is romantic, because this unquestionably valuable property still does not necessarily result an optimal solution. However, being romantic does not guarantee formal expressivity: the engineering of shells is not necessarily the engineering of excitement (Boyd, 1958).

The general, rather pragmatic approach of Hungarian engineers towards (shell) architecture is best summarized by Menyhárd, in a response to a manifesto of rational architecture published by Jenő Szendrői (Szendrői, 1964), influential leader of IPARTERV: “(...) from an engineer's point of view, making such statements, as 'the labour and material usage must be minimized' or (...) 'maximize the outcome while minimize the costs' (...) is a mere waste of time - they are so evident." 28 (Menyhárd, 1965. 117-118.)

This approach might have been influenced by the social-political context, the deductive character of the Hungarian engineering education, but nevertheless: by the time shell architecture got a chance in Hungary, its focus on economy and structural soundness over formal considerations was considered outdated internationally.

\footnotetext{
${ }^{26}$ Isler stated, that " $(. .$.$) he can analyse many of his shells approximately, by hand, in a few seconds. (..) in$ the majority of the surface they [the occurring stresses] are not even 15\% of what is allowed, so even quite large approximations are insignificant." (Chilton, 2000, 38)

${ }^{27}$ While Csonka published relatively early on abroad (e.g. Csonka, 1966), Kollár and Tarnai were and have been actively involved with the IASS, the International Association of Shell Structures.

${ }^{28}$ See 'Appendix' for the full citation in original.
} 


\section{CONCLUSION}

"Interestingly a structure that defines a new trend is always based on an idea of a more efficient solution. Any trend has followers. (...) The first type of followers end up imitating by trying to avoid it, while the others take pleasure in following a good lead, and by doing so, end up creating something unique." (Pelikán, 1964)

The brief summary presented above of the contemporary international trends compared to the Hungarian developments suggests that Hungarian shell architecture was eminent in adaptation, in the best possible sense. Considering the special circumstances of the socialist industrialization, the major field of application of shells in Hungary, originality was not a prerequisite - ingenuity to come over the lack of resources was. Hungarian shell architecture is a testimony for that. No more - no less.

\section{ACKNOWLEDGEMENT}

The authors would like to express their gratitude for their valuable help and comments to Dr. Endre Dulácska, Dr. Tibor Tarnai and János Dobai, DLA representing the MIEA Archive for IPARTERV. Many students of architecture participated in the research project, the authors would like to thank Veronika Szkiba in particular for her involvement. The research project is supported by the Grant 3202/00512 of NKA (National Cultural Fund, Hungary).

\section{REFERENCES}

Addis, Bill: Building - 3000 Years of Design, Engineering and Construction. Phaidon, London 2007.

Aimond, Ferdinand: Etude statique des voiles minces en paraboloïde hyperbolique travaillant sans flexion. IABSE Proceedings (1936) 4. 1-112.

Arup, Ove: Some recent notable shell structure designs. In: Concrete Shell Roof Construction: Oslo, 1957. Aas \& Wahl, Oslo 1957. 1-11.

Arup, Ove - Jenkins, Ronald S.: The design of a reinforced-concrete factory at Brynmawr, South Wales. Proceedings of ICE 2 (1953) 6. 345-379.

Baudisch, Andreas: Was besonderes. Kunsttexte. http://edoc.hu-berlin.de/kunsttexte/2013-3/ baudisch-andreas-3/PDF/baudisch.pdf (Accessed 15.07.2016.)

Boyd, Robin: Engineering of Excitement. AR 124 (1958) 742. 294-308.

Bölcskei Elemér: A héjszerkezetek hazai fejlődése / Developments of shell structures in Hungary. MÉI 19 (1970) 5. 257-266. In Hungarian

Chilton, John: Heinz Isler. Thomas Telford, London 2000. 38.

Chiorino, Cristiana (ed.): Pier Luigi Nervi. Architecture as challenge. Silvana, Milano 2011.

Csonka Pál: Kuppelschalen über Polygongrundrissen. In: Stefan Polónyi (ed.): Schalen in Beton und Kunststoff. Bauverlag, Berlin 1970. 61-95.

Csonka Pál: Membranschalen. Ernst, Berlin 1966.

Dobai János: Stahlbetonvorfertigung vor Ort - Zur Geschichte der Kraftwerke in Ungarn. In: Peter, Markus (ed.): Technik \& Systeme 4. ETH, Zürich 2013. 
Erényi Iván: Menyhárd István. Akadémiai Kiadó, Budapest 1990. In Hungarian

Espion, Bernard: Pioneering hypar thin shell concrete roofs in the 1930s. Beton- und Stahlbetonbau 111 (2016) 4. 159-165.

Farkas Ipoly: Székesfehérvári Könnyűfémmü. MÉI 10 (1961) 1. 1-3. In Hungarian

Galantay, E.Y: Les voiles minces et la couverture autoportante. AA (1956) 64. 28-45.

Gáspár Orsolya - Sajtos István: Parallel Universe - Evolution of Hungarian shell architecture In: Proceedings of the IASS Annual Symposium 2016.

Gnädig Miklós: Vorgefertigte Stahlbetonfachwerk- und Stahlbetonträger in Ungarn. In: Die Montagetebauweise mit Stahlbetonfertigteilen und ihre aktuellen Probleme. Berlin, 1956 120-129.

Haas, A.M: Prestressed and precast shells. In: Concrete Shell Roof Construction: Oslo, 1957. Aas \& Wahl, Oslo 1957. 1-8.

Harasta Miklós: Héjlefedésű ipari épületek / Industrial buildings with shell roofing. MÉI 8 (1959) 8. 320-321. In Hungarian

Horváth Csongor: Héjszerkezetủ shed-csarnok / Shell-covered hall with northlights. MÉI 12 (1963) 10. 453-457. In Hungarian

Kollár Lajos: A Székesfehérvári Könnyüfémmü bővítés II. ütemének héjszerkezetei / The shell structures of the second phase of Székesfehérvári Könnyüfémmü. MÉI 19 (1969) 11-12. 541-545. In Hungarian

Kollár Lajos - Dulácska Endre: Buckling of shells for engineers. Akadémiai Kiadó, Budapest 1984.

Kurrer, Karl-Eugen: The history of the theory of structures. Ernst und Sohn, Berlin 2008.

Mainstone, Rowland: Developments in Structural Form. MIT Press, Cambridge, Mass. 1975.

Melaragno, Michele: An Introduction to Shell Structures: The Art and Science of Vaulting. Springer. New York 1991.

Márkus Gyula: Theorie und Berechnung rotationssymmetrischer Bauwerke. Werner Verlag, Düsseldorf 1978.

Menyhárd István: Héjszerkezetek elmélete / Theory of shells. BME Mérnöki Továbbképző Intézet, Budapest 1942.

Menyhárd István: Hozzászólás dr. Szendrői Jenő „A konstrukció és konstruktőr szerepe a mai építészetben" c. előadásához. MÉI 14 (1965) 2. 117-118. In Hungarian

Menyhárd István - Semsey Lajos: A Csepeli Csőgyár hegesztőcsarnoka. MÉI 11 (1962) 4. 156-159. In Hungarian

Menyhárd István: Túlhaladott-e a monolitikus építési mód? / Is cast-in-situ shell construction outdated? MÉI 9 (1960) 2. 73-76. In Hungarian

Mokk László: Bauen mit Stahlbetonfertigteilen. Verlag der Ungarischen Akademie der Wissenschaften, Budapest 1960.

n.a.: La préfabrication lourde appliquée aux constructions industrielles en Hongrie. AA (1959) 83. 92-97.

n.a.: Bâtiments industriels. $A A$ (1961) 95. 56-65.

n.a.: Premiere attribution des prix "Auguste Perret" et "Sir Patrick Abercombie" 1961. AA (1961) 95.

n.a.: Hungary builds. $A R 130$ (1960)

n.a.: Hungarian Industrial. AR 133 (1963)

Pál Balázs - Reisch Róbert: A csepeli Szerszámgépgyár héjszerkezetủ csarnoka / The hall covered with shell roof for the Szerszámgépgyár, Csepel. Müszaki Tervezés 8 (1968) 4. 19-21. In Hungarian

Pelikán József: A szerkezettervezésről általában / On structural design. MÉI 13 (1964) 3. 167-175. In Hungarian

Reisch Róbert: Visszapillantás egy monolit héjszerkezetủ ipari csarnokra / Retrospective: an industrial hall covered with cast-in-situ shell. MÉI 21 (1972) 4-5. 205-208. In Hungarian

Reisch Róbert: Shell Structures in Hungary. In: Proceedings of the IASS Annual Symposium 1965. Budapest 1968.

Rühle, Hermann: Bemerkenswerte Neuere Entwicklungen der Schalenbauweise in Bulgarien, der CSR, Polen, Ungarn und Deutschland. In: Concerte Shell Roof Construction: Oslo, 1957. Aas \& Wahl, 
Oslo 1957. 1-18.* (the page numbering is not a misspell, the volume does not have continuous numbering)

Szendröi Jenő: A konstrukció és konstruktőr szerepe a mai építészetben / The role of design and designer in present day architecture. MÉI 13 (1964) 3. 143-151. In Hungarian

Szmodits Kázmér: Héjszerkezetek statikája / Statics of Shells. Akadémiai Kiadó, Budapest 1953. In Hungarian

Tarnai, Tibor: Existence and uniqueness criteria of the membrane state of shells I. Acta Technica Academiae Scientiarum Hungaricae (1980) 91. 81-110.

\section{APPENDIX}

\section{ABBREVIATIONS}

MÉI Magyar Építőipar

AR The Architectural Review

AA L'Architecture d'Aujourd'hui

IASS International Association of Shell Structures (today IASSS = International Association of Shell and Spatial Structures)

MIEA Magyar Ipari Építészetért Alapítvány

\section{ORIGINAL TEXTS}

1 “(...) die Anwendung von Schalen in Ungarn [ist]nicht so ausgeprägt. Ungarn verwendet für Industrieflachbauten u.a. vorwiegend vorgefertigte Rahmen-, Vierendeel- und Fachwerkkonstruktionen und hat in dieser Hinsicht eine meisterhafte Entwicklung gezeigt." (Rühle, 1957)

20 “(...) including two, that will look immediately familiar to the western eye (...) The date of this structure - 1955 would give it something of a pioneering status anywhere in the world (for some reason it did not receive the publicity it deserved at the time of its completion) (...)"

${ }^{25}$ „,(...) Nem akarok itt részletekkel foglalkozni, de mérnöki szemlélettel nézve a dolgot, ilyen tételeket mint: ,,az elöállításhoz a legkevesebb anyagot és munkaeröt kell felhasználni”, hogy ,, a legkisebb ráfordított költségért a legtöbbet kell kapni”, hogy ,a legolcsóbb és leggazdaságosabb megoldás az ipar fejlettségétöl függ”, stb., ha egy gépészmérnöknek magyaráznánk, aki történetesen motorokat tervez, kinevetne és azt mondaná, hagyjuk békében, ne lopjuk az idejét fölösleges dolgokkal, ezek magától értetödö dolgok." 


\section{PICTURE CREDITS}

Courtesy of MIEA: Fig. 1, 7, 9, 10 (KÖFÉM), 11, 14 (KÖFÉM), 15(Csepel), 17(archive)

Fig. 2 - authors

Fig. 3 - https://41.media.tumblr.com/tumblr_m8g81fAfTK1qm9rypo1_r1_1280.jpg (Accessed 16.08.2016.)

Fig. 4 (CNIT) - http://66.media.tumblr.com/tumblr_1410j2a3fg1qzfye6o1_1280.jpg (Accessed 16.08.2016.)

Fig. 4 (Müther) - Müther Archiv (Accessed 16.08.2016.)

Fig. $5-$ https://s-media-cache-ak0.pinimg.com/736x/62/61/55/62615509087a4fc436c96dd01e239195.jpg (Accessed 16.08.2016.)

Fig. 6 (Frankfurt) - by Robert Metsch - European Central Bank, http://images.cdn.baunetz.de/ img/7/9/6/4/4/1/80a41978477ab04c.jpeg (Accessed 16.08.2016.)

Fig. 6 (Budapest) - Fortepan (Accessed 16.08.2016.)

Fig. 8 (Miskolctapolca) - by Éva Michelisz

Fig. 8 (Eger) - by Éva Michelisz

Fig. 10 (Brynmawr) - http://www.engineering-timelines.com/itempics/factory/brynmawr CCA_380x235.jpg (Accessed 16.08.2016.)

Fig. 12 - MÉI 1969

Fig. 13 - Mokk, 1960

Fig. 14 (Manchester) - Mokk, 1960

Fig. 15 (Brynmawr) - by Iain Wright

https://www.peoplescollection.wales/sites/pcw/files/images/2014/February/DI2008_0464.jpg (Accessed 16.08.2016.)

Fig. 16 - http://images.adsttc.com/media/images/5346/2042/c07a/80a7/6e00/00a6/large_jpg/Wiki_ Los_Manantiales_(4).jpg?1397104702 (Accessed 16.08.2016.)

Fig. 17 (present) - Bence Hargitai 


\title{
AZ ISMERETLEN GAZDASÁGOSSÁGA - A HÉJÉPÍTÉSZET ÉS AZ IPAROSÍTÁS VISZONYA MAGYARORSZÁGON 1949-1970 KÖZÖTT
}

\author{
Összefoglaló
}

A vasbeton héjépítészet története szorosan kapcsolódik a XX. század első felét jellemző gyors és széleskörü iparosodáshoz. Az ipari termelés nagy fesztávú csarnokokat igényelt, ezek lefedésére tökéletesen alkalmasnak mutatkoztak a mérnöki eszköztárban akkoriban megjelenő vasbeton héjak. Az alábbiakban a hazai héjépítészet fejlődésének sajátosságait mutatjuk be, más, korábbi szocialista országokkal, illetve nyugat-európai trendekkel összevetve. A KÖFÉM gyár lefedésére kidolgozott csarnoktető fejlödésének ismertetésén keresztül vizsgáljuk az egyéni teljesítmény és a nemzetközi hatások jelentőségét.

A szovjet érdekszféra elszigeteltsége, eltérő társadalmi és gazdasági berendezkedése miatt a XX. század második felében a nyugati szaksajtó az ismeretlennek kijáró érdeklődéssel számolt be a 'Keleti Blokk'-ban zajló műszaki- és építészeti folyamatokról. A korábbi szocialista országok huszadik századi építészettörténetének feldolgozása napjainkban is zajlik, ezzel összefüggésben a nemzetközi érdeklődés a korszaki iránt újra fokozódik. A dolgozat második fele a korszak magyarországi ipari, illetve elsősorban héjépítészetének korabeli nemzetközi recenziójával foglalkozik. Reményeink szerint ez hozzájárul a korszak hazai eredményeinek objektívebb megítéléséhez, melynek jelentősége, hogy a korszak alapvető forrásanyaga, a korabeli hazai szaksajtó nem mentes a szocialista rendszer önigazolási kényszerétől.

Kulcsszavak: héjépítészet, vasbeton, ipari építészet, szerkezeti elemzés, szocialista modernizmus 